\title{
Charcoal Power: \\ The Political Violence of Non-Fossil Fuel in Uganda
}

\begin{abstract}
:
The politics of global energy are subject to increasing academic interest. Most work on energy politics focuses on oil, based upon a normative vision of a global energy modernity of fossil fuels and a transition to renewables. In most African countries, however, the primary source of energy is not oil, but woodfuel. Charcoal is of particular importance due to its centrality to urbanization: charcoal is the primary energy source for up to $80 \%$ of urban Africa, and its consumption is expected to continue increasing with expanding urbanization. Despite this centrality, the politics of charcoal remain largely unexplored. This article explores how political power shapes charcoal production and how charcoal as an energy source shapes political power through an in-depth study of charcoal extraction in northern Uganda. It argues that charcoal production, and its particular destructiveness, should be understood as a continuation of the violence of the 1986-2006 war between the Lord's Resistance Army and the Ugandan government. Based on several months of fieldwork in Northern Uganda, the article draws a distinction between the politics of small-scale household production and of large-scale industrial production. By focusing on the political violence of industrial charcoal production, we argue that orthodox academic and policy narratives about the charcoal industry in Africa can be qualified, and new questions can be raised concerning broader narratives of energy modernity and global energy politics.
\end{abstract}

Key Words: Charcoal - Uganda - Africa - Energy politics - Political violence Extractivism 


\section{Introduction: The Power of Non-Fossil Fuels in Africa}

In Carbon Democracy, Timothy Mitchell argues that, to understand the relation between oil and politics, we need to focus upon the materiality of oil and avoid the abstractions of the dominant "resource curse" literature. That literature removes oil from its social and political context, from the earth it is buried in, the workers and infrastructures that extract and move it, the military forces that protect it, and the acts of resistance that sabotage it, occluding the ways that oil's global circulation powers politics. Instead, we need to "follow the production and circulation of oil itself" in order to comprehend democracy "as a form of politics whose mechanisms...involve the processes of producing and using carbon energy" (Mitchell, 2011: 5).

We follow Mitchell's method, while questioning the implication that the modern world is one everywhere based on oil, and that, to understand the politics of global energy modernity, oil must be at the center of analysis (Urry, 2014). Indeed, in much of Africa, oil may not be the form of carbon energy whose processes of production and consumption most shape and power politics. Of course, it is crucial in states with large oil industries, and oil has a key role throughout Africa in sustaining transport systems, enabling middle-class and elite lifestyles, and integrating national and global economies (Bassey, 2012; Soares De Olivera, 2015; Watts, 2009).

In many African countries, however, it may be non-fossilized carbon, in the form of firewood or charcoal, that is the energy source most bound up with politics, even if in less spectacular fashions. The numbers would seem to support this proposition: 
woodfuels meet 90 percent of sub-Saharan Africa's household energy needs and about $80 \%$ of "total final energy consumption" (IEA, 2014: 131; excluding South Africa). Charcoal is the primary energy source for about 80 percent of urban households, while firewood is the primary source for about the same percentage of rural households. Of global charcoal production, $61 \%$ occurs in Africa (Doggart and Meshack, 2017; citing FAO, 2016), and Africa's rapidly growing urban populations mean that charcoal consumption is expected to rise another $50 \%$ between 2010 and 2030 (Broadhead et al., 2001; in Arnold, 2006: 599; see also the projections in IEA, 2014). ${ }^{1}$

In Uganda, the focus of this article, charcoal is the primary energy source for about $70 \%$ of urban households, rising to $90 \%$ in Kampala (Mukwaya, 2016; MEMD, 2016; UNDP 2013). Two million metric tons of charcoal are produced each year (MEMD, 2016), and, with Uganda's urban population expected to double between 2010 and 2040, charcoal demand is estimated to be increasing annually at 3\% to $6 \%$ (MEMD, 2016; UNDP, 2013). Hundreds of thousands of people in Uganda depend on charcoal as a source of income (Mwampamba et al., 2013), and it has even been said to be the highest-earning cash crop for rural Ugandan households (WWF 2015).

Despite the centrality and growing significance of charcoal to lives and livelihoods in urban and rural Africa, the burgeoning literature on the politics of energy makes little mention of it (Vanderheiden 2011; Boyer 2014; Huber 2015). When charcoal does appear, it tends to be relegated to the status of a "traditional," non-modern fuel, a symptom of energy poverty and energy injustice (Sovacool and Dworkin, 2014; Jones, 2016). However, there is nothing "traditional" about charcoal as a fuel; its 
widespread use is bound up with postcolonial urbanization, it is integrated into global and regional trade networks, and, in some places, it is a key fuel for industry. There are still no comprehensive investigations into charcoal power in Africa: a few works explore how political power shapes charcoal (Ribot 1998; Cavanagh et al. 2015; Bergmann et al. 2018), but the question of how charcoal shapes political power and the longer political-economic-ecological histories in which it is produced and consumed remain woefully under-researched. Despite its centrality to social life in much of Africa, it has largely gone under the political radar, in part due to the assumptions surrounding it, as detailed below. By looking at charcoal as a question of energy and political form, we can start to delineate the entwined power relations, both political and energetic, that are bound up in charcoal's production, transport, and consumption, locally, nationally, and internationally. We can ask about the state forms that charcoal enables, the social structures that charcoal produces, and the possibilities and limitations of those politics. It allows us to better grasp African countries' position within international energy economies and global political ecologies.

Approaching charcoal in this way also allows it to be located within history. Charcoal is part of longer histories of energy, resource extraction, rural-urban relations, state control over forests and peoples, and, in cases like northern Uganda, war and political violence. In charting out an approach to charcoal power, this article focuses on the production and transport of charcoal within Uganda's northern region over the last ten years, that is, since the end of Uganda's two-decade war between the Lord's Resistance Army and Ugandan government in 2007. While it does not address longterm histories of energy or environmental politics, it does draw on a more recent 
history for its central argument: that today's charcoal politics can be understood only by placing charcoal extraction within the history of the war's physical and social devastation. ${ }^{2}$ To understand charcoal's particular destructiveness, its production and trade must be seen as made possible by, and exacerbating, legacies of the war. In certain aspects, charcoal extraction can even be seen as a continuation of the war through different means and under different conditions of state violence against civilians.

Ignoring this history and context leads to untenable technical "solutions" being put forward to the problems associated with charcoal in Uganda, centered around better regulation, increased monitoring, and technological innovations such as fast-growing tree species and improved kilns and stoves. In a way, this too reprises another aspect of the concluded war: technical international interventions, whether humanitarian, peacebuilding, or legal, that ignore politics and end up being ineffective or counterproductive (Branch 2011). Thus, the history of violence in northern Uganda needs to be taken into account if today's environmental interventions are not to fall into the same patterns of the past. Before coming to that history, we turn first to charcoal's treatment in two bodies of academic and policy literature: the energy transitions literature and the rural development literature. We argue that both tend to ignore the power of charcoal because both abstract charcoal from the political histories it is embedded in.

Data for this paper have been gathered through a set of qualitative research methodologies including fieldwork, participant observation, community dialogues, focus groups and semi-structured interviews conducted in five charcoal-producing 
districts of Acholi sub-region of northern Uganda during several months in 2017. Specifically, community members were interviewed collectively through dialogues and within cross-cutting sub-groups, such as women, elders, and youth. Questions focused on the history, character and scope of charcoal production, the extent of tree cutting and the groups involved, the benefits, in particular monetary income, and problems, including deforestation, loss of biodiversity and climate change associated with charcoal burning. Interviews also looked to place charcoal in the context of broader agrarian transformations and the legacies of war. In-depth, semi-structured interviews were conducted with key informants selected among local government officials, politicians, intermediaries, brokers, and labor crews, and concerned issues of policies and trade regulation, prices and licenses, and labour and modes of production. This approach allowed seeing charcoal production from multiple perspectives providing us with several entry points into the research questions. ${ }^{3}$

\section{Charcoal between Tradition and Modernity}

When charcoal does make an appearance in the literature on the global politics of energy, it is largely only to be dismissed. The energy transitions framework often underlying this literature tends to have a teleological analytical and normative bias towards fossil and post-fossil fuels, and so charcoal is presented as an atavistic, traditional, pre-modern form of energy, akin to firewood, dung, and agricultural residues, giving way to an inevitable global fossil fuel or post-fossil fuel modernity. This framework underlies high-modernist development visions propagated by many African states, which assume that charcoal will be left behind in state-led transitions to fossil fuels, hydropower, and nuclear energy (Doggart and Meshack, 2017; 
Mwampamba et al., 2013). For instance, Uganda's National Development Plan of 2010 calls for full energy modernization in 30 years, while Uganda Vision 2040 (NPA, 2013) declares that, "For Uganda to shift from a peasantry to an industrialized and largely urban society, it must be propelled by electricity as a form of modern energy," (73) and projects nuclear becoming Uganda's primary energy source. The widely contested notion of an "energy ladder" can underlie this vision: a Ugandan think-tank invokes the need to "transition from firewood and charcoal through kerosene to LPG and electricity;" thus, "when households climb the energy ladder, forest resources utilization reduces as less of firewood and charcoal are required" (Mwaura et al., 2014: 4). In such teleological thinking, charcoal is abstracted from its material, historical context and understood simply as a step in a supposed energy ladder (Hiemstra-van der Horst and Hovorka 2008). The result, as Zulu and Richardson write, is that "too much faith in the 'energy transition' theory has undermined realistic, proactive policy-making on charcoal" (2013: 128).

However, research has made clear that dismissing charcoal as being on its way out is unwarranted. Mwampamba et al. (2013) argue that there is in fact no evidence for a general "energy transition" through charcoal to electricity or fossil fuels. In fact, the proportion of African urban households using charcoal as their primary fuel is itself increasing (ibid.; Zulu and Richardson, 2013). The numbers can be dramatic: in Tanzania, for instance, a $1 \%$ increase in urban population leads to a $14 \%$ increase in wood consumption (Mwampamba et al., 2013). Even industrialization may lead to greater demand for charcoal and other wood fuels, not less. In Uganda's case, the possibility of large-scale fuel switching envisioned by energy modernization appears minimal (MEMD, 2013: 77-8; Mann et al., 2014). This reality requires qualifying the 
normative model of a fossil-fuel "energy modernity" as Africans climb the energy ladder (Barnes et al., 2004). The sustained co-existence and competition of biomass fuels, fossil fuels, and non-carbon renewable energy may not be a sign of an ongoing transition (Sovacool 2012). Rather, charcoal's importance to urbanization, to global trade networks, to rural incomes, and to industry means that this mix, if anything, is energy modernity in much of Africa.

The tendency to dismiss charcoal in the energy transitions literature also derives from the view of it as inherently and uniformly ecologically destructive and, thus, unsustainable. This negative portrayal resonates with fears in the 1970s of a coming "woodfuel crisis" in the face of expanding populations and dwindling forest stock (Arnold et al., 2006). Charcoal's supposed unsustainability has taken a global dimension with concern over its contribution to global greenhouse gas emissions (Chidumayo et al., 2013) as well as interest in the possibility of "green charcoal" creating carbon emissions credits (Bailiss et al., 2015).

Today, the degree to which charcoal extraction is contributing to deforestation and forest degradation is a subject of intense debate (Bergmann et al., 2018). Catastrophe narratives continue to abound, but the categorical identification of charcoal with deforestation and ecological unsustainability has been robustly challenged as a "myth" (Mwampamba et al., 2013; Chidumayo et al, 2013), much as the "woodfuel crisis" narrative was previously (Chidumayo 1987, 1993; Leach and Mearns, 1988; Fairhead and Leach, 1998). Much research on charcoal agrees that there is little conclusive evidence that its production is a major driver of deforestation on a global or even regional level when compared to other causes, in particular the expansion of 
large-scale commercial farming, ranching, and commercial timber, the beneficiaries of which are happy to use charcoal production as a scapegoat. However, Chidumayo et al (2013) point out that even if deforestation from charcoal is relatively minor at a global or regional scale, it can be dramatic at a local or national scale. Bailis et al (2015) have identified woodfuel "hotspots" where current extraction is deemed unsustainable, with the largest "incorporating a swath of East African extending from Eritrea through western Ethiopia, Kenya, Uganda, Rwanda and Burundi.”

What this points to is that the ecological impact of charcoal should be categorically deemed neither catastrophic nor negligible. Indeed, charcoal can be produced in many different ways with many different ecological impacts. What the impact of charcoal production is - and thus whether it is sustainable or not - is partly a technical question involving cutting practices, kilns, and stoves. But, as the case of northern Uganda demonstrates, it is also a political question: in situations where charcoal production and trade are controlled by those who do not have to deal with the ecological destruction they wreak, and where there is no accountability to those populations who do pay the price, ecologically devastating but highly profitable modes of production may be the norm. Maintaining the transitions myth that charcoal is on its way out and should be on its way out allows states to disavow responsibility for the industry and its damage, at the same time that powerful actors, often with state connections, take advantage of the lack of legal regulation and public accountability to reap enormous profits at the cost of rural communities. New thinking about national development would thus have to start with a recognition of the many possibilities of charcoal within a broader energy mix (WWF 2015), while also grappling with the often very difficult politics of charcoal and other energy sources. 


\section{Weak Links in Charcoal Value Chains}

The literature that does take charcoal seriously as an important present and future energy source is the rural development literature, with an emphasis on forest products, livelihoods, and land-use change, which has helped foster a positive reassessment of charcoal in some development thinking (Arnold et al., 2006; Sola et al., 2017). This literature largely comprises market-oriented analyses and recommendations for regulation of charcoal value chains. It focuses on problems commonly associated with the charcoal industry - that it is exploitative towards rural producers, a lost source of government revenue, and a potential cause of deforestation and ecological damage and responds with calls for regulation and improvements to the value chain. In the words of UNDP (2013: 8), charcoal is "an important opportunity to help shape future low carbon development", since an "improved charcoal value chain" would remove a "major driver of deforestation while increasing energy security and sustainability." However, except for a few contributions, this mostly policy-oriented literature, due to its underlying assumptions, also largely misses the politics of charcoal. This is illustrated by the literature on Uganda.

First, the dominant value-chain literature tends to assume that charcoal production is everywhere carried out by many dispersed, very poor, individual or household rural charcoal producers, who earn very little. The UNDP (2013: 18) declares that, in Uganda, "charcoal production is predominantly undertaken by rural populations in unorganized groups or individuals," with the assumption that "charcoal producers constitute the 'poorest of the poor'" (ibid: 38). Uganda's Ministry of Energy and 
Mineral Development agrees, describing the "small scale individual producers who dominate the sector" (2015: 5). The producers are often assumed to be using household labor and rudimentary tools and techniques and to have few alternative livelihood opportunities.

Second, the dominant literature often tends to assume that the charcoal value chain represents a series of market transactions. Unorganized producers are described as connected by agents to a number of competing transporters, who then connect to a distinct set of wholesalers and retailers in urban areas, with little vertical integration (Shively et al., 2010). Middle-men or elite merchants are often seen as the problem, with "a large spectrum of people looking to take advantage of the relatively high price difference between the money paid to the producers and the final price paid by consumers" (UNDP, 2013: 22). This dominant picture assumes that involvement in charcoal production is so skewed against producers - securing only $5-10 \%$ of the total proceeds (UNDP, 2013) - that charcoal may be further impoverishing the rural poor who are involved in its production or who live in areas from where trees are extracted.

Third, much of the dominant literature on charcoal in Africa tends to assume that production and trade exist in a regulative vacuum characterized by "weak, misguided, neglected, underdeveloped, disjointed, overly prohibitive, contradictory or nonexistent woodfuel policies and laws, combined with poor enforcement and regulatory capacity" (Zulu and Richardson, 2013: 130), and that this regulation deficit is to blame for charcoal's negative consequences. The focus is on a lack of legal regulation: in Malawi, for instance, all production is illegal (Smith et al., 2015), and in Tanzania, $80 \%$ of the trade is outside the legally-regulated market (Sander et al., 
2013). In many places, including Uganda, charcoal is presented as being in a legal grey area. Uganda's decentralization and the multiplication of under-resourced districts, according to reports, has led regulation to vary dramatically but to be uniformly ineffective (MEMD, 2016: 89-96; Shively et al., 2010). Nationally, regulatory frameworks are scattered across different agencies without cohesion. A national survey reported widespread uncertainty among government officials and dealers as to requirements for legal production (MEMD, 2016: 24). Uganda's National Forestry Act provides few guidelines for forest on non-state lands, the source for almost half the wood for charcoal (MEMD, 2016: 29-30). Government interventions thus take a "fire-fighting" approach through ministerial declarations or district ordinances comprising sweeping bans, often with little effect (MEMD, 2013: 91; Wandera, 2016; Owich, 2016). The regulation deficit is said to extend to communities living among forests, who supposedly require legal enforcement so that the illegal, wanton cutting of trees is stopped (as described by Cavanagh et al, 2015).

In short, according to this dominant picture, a coordinated effort of technical regulation and technological innovation is needed to improve the value chain so as to benefit livelihoods and lives of rural producers, stop illegal production and transport, expand the fiscal basis of the state, and promote local, national, and global sustainable development, all while ensuring "energy security" for urban areas. This dominant picture has not gone uncontested, however, by a more critical strand in charcoal research. First, the idea that charcoal is everywhere produced by small-scale, unorganized, mostly male, and deeply impoverished producers has been qualified by a recognition of diversity among producers. Researchers report many different reasons why people, including women, produce charcoal (Smith et al., 2017), and the different 
impacts it can have upon rural livelihoods, sometimes representing a major source of rural employment and income (Mwampamba et al., 2013; Schure et al., 2015).

Reasons for producing charcoal are also tied into broader systems and transformations of land tenure and labor regimes (Bergmann et al., 2018; Barney 2016). In Uganda, for instance, Khundi et al. (2011) show that charcoal producers tend to be better off than non-producers, and so charcoal production should not necessarily be identified with the "poorest of the poor" (see also Ainembabazi et al., 2013).

The ubiquity of small-scale, household labor has also been questioned. In some cases, rural inhabitants are not themselves producers but, rather, provide land or trees to be cut and burned by migrant work crews (Minten et al., 2013). In Mozambique, Baumert et al. (2016) identify two distinct charcoal value chains, one involving smallscale, household-based operators and producers, and the other large-scale operators with hired labor, access to trucks, and machines for cutting the wood; this will resonate with the northern Uganda case. Ribot's (1998) work on charcoal in Senegal describes an industry dominated by urban-based elites who contract and bring in foreign work crews to cut down large swaths of trees on villagers' land and reap enormous profit. Even Uganda's National Charcoal Survey provides evidence that cuts against its own assumption of the ubiquity of small household producers with little or no horizontal or vertical integration. It explains that almost half of all producers work on charcoal full-time and half buy their wood instead of collecting it themselves, with almost all practicing clear-cutting (MEMD, 2016: 34), suggesting that much of the industry comprises full-time contracted laborers. Merchants also reported the existence of cartels that exert a heavy influence on the trade (ibid: 68), again suggesting an industry not entirely dominated by small producers and 
unorganized transporters. Shively et al. (2010) describe significant differences in labor arrangements even among neighboring districts, with small-scale and largescale production sitting side-by-side. However, as we address below, little has been done to analyze the political and social implications of these diverse modes and scales of production. The result is that the picture of a multitude of small-scale individual producers often tends to be taken for granted, and so the problems that may be due to large-scale production end up blamed on the rural poor.

The assumption that a deficit of legal regulation is driving the problems of the charcoal industry has also come into question as increased attention has been turned to the institutions, both formal and informal, that in practice control production and trade in the absence of, or in complex relations with, legal regulation (Cavanagh et al 2015; Schure et al. 2015). Thus, the presence or absence of legal regulation may be of less importance than whether the industry is controlled by powerful formal institutions, often part of the state or its security services, or whether it is controlled by and accountable to informal, community-based arrangements and institutions (Baumert et al., 2016). A lack of functioning legal regulation does not imply disorder and the need for more law: the law can be captured by powerful state actors, as Ribot's (1998) work on Senegal's charcoal business makes clear. The question thus becomes how to promote informal, community-based forms of regulation (Doggart and Meshack, 2017) in a context where 'heightened forest law enforcement may actually exacerbate already existing conflicts between government entities and local communities' (Cavanagh et al 2015, 76). 
Attention to the range of formal and informal state and community institutions that underpin a legally unregulated industry has brought the question of power into work on charcoal. Typically, however, the concept is limited to the power to access and shape markets and control resources to extract rents (Minten et al., 2013; Sander et al., 2013), a limitation tied to the continued primacy given to small-scale, household production despite the frequent recognition of large-scale charcoal production. Along with Ribot (1998), Cavanagh et al (2015) are among the few to explicitly raise the question of political involvement in the charcoal industry. Cavanagh et al conclude that the involvement of powerful state and military actors characterizes the East African timber trade more than the charcoal trade, and that those cases where charcoal does have major involvement by state or non-state military forces - such as AlShabaab in Somalia - are of a relatively minor scale. This may be the case, but it does not detract from the need to identify the presence of state or military force in charcoal production where it does occur and to distinguish between its political, economic, and ecological consequences versus the consequences of small-scale livelihood production. A helpful starting point can be found in Bergmann et al's (2018) proposal to see charcoal as part of a 'fuelscape' - or perhaps an 'energyscape' - which would map the 'contested meaning of commercialized charcoal production in temporal, material and social terms" (2), with attention to "dynamics involv[ing] multiple spatial scales (such as the urban, regional and national), sectors (such as forestry and energy) and stakeholders (including policy-makers, consumers, brokers, sellers and producers' (6). Thus, whether we are seeking to understand the politics of charcoal extraction in northern Uganda's disappearing forests, in commercial woodlots, or in Kismaayo, Somalia, where millions of bags are stacked up, prepared for export to the 
Gulf and fought over by different military forces, we should explore multiscalar histories of charcoal production within larger political and ecological histories.

This would mean starting with the political structures within which forms of charcoal extraction, labor, and distribution take place, which sometimes take a market form, instead of starting with the assumption that politics is an exogenous institutional framework or set of pressures that shape the market-based value chain. These political structures have specific histories, in which violence can play a role; thus, aspects of the industry such as informality, coercion, or unequal access may not be problems of an inefficiently operating market but may be understood as a productive part of social and political structures - part of a "resource complex" - not deviations from a market norm (Watts and Peluso, 2014). Indeed, a recent literature survey (Sola et al., 2017) finds few studies considering charcoal at the national level and a neglect of the history and institutions around production. The result is that much of the existing literature, by abstracting charcoal from its historical, national, and international contexts, does little to address broader questions about charcoal power, which may be needed to enable the "radical rethinking" of charcoal policy often called for (Zulu and Richardson, 2013: 135; Smith et al., 2017).

In summary, while the dominant picture of the industry - comprising small-scale, desperately poor charcoal producers, within a chain of unregulated market transactions, leading to significant ecological destruction - is still prevalent, in particular in the policy literature, it has been greatly qualified. However, even this more empirically robust literature has yet to deal extensively with the political power of charcoal, which becomes especially important when considering the very different 
political, social, and ecological implications of small-scale and large-scale production. The case of northern Uganda shows that distinguishing between different modes of production is crucial, for migrant work crews and local livelihood producers will have very different relations to merchants, communities, the state, and forests. Failure to do this allows blame for charcoal-related deforestation to be shifted to a supposed "tragedy of the commons" among many destitute local-level producers (see Hardin, 1968), taking attention away from other causes and the divergent range of modes of charcoal production. Analytical and policy work needs grounded and empirically informed sociological accounts along class, gender, ethnic and generational lines of what is sometimes presented as an undifferentiated Ugandan countryside (Bernstein, 2010; White et al., 2011). In what follows, we try to raise some of these broader questions by focusing on one specific section of Uganda's charcoal industry.

\section{Charcoal in Post-War Northern Uganda}

Charcoal production in northern Uganda is recent, but its growth has been dramatic. Today, almost $40 \%$ of Uganda's supply of charcoal to urban areas is reported to come from the north, whereas ten years ago it was near zero (MEMD, 2016: 57). Charcoal is the subject of intense media and public attention in northern Uganda and at the center of emphatic narratives of ecological crisis. Stories abound of forests that have disappeared and people being unable to recognize formerly familiar landscapes. The available statistics signal how extensive tree extraction has been: in 2014, it was reported that Gulu and Amuru districts' forest cover had been almost halved since 1990 (Laker, 2014). It has been estimated that 4-5000 bags of charcoal are being removed from just one district every week (Owich, 2016; Miteva et al., 2017). 
Nationally, there is talk of a "looming charcoal crisis" (Sserunjogi 2014), based upon the fact that an estimated 44 million tons of tree biomass are used each year for energy, which could rise to 135 tons, but that tree resources can sustainably supply only 26 million tons (MEMD 2013). Forest cover is said to have shrunk over the last 100 years from 10 million hectares to 3.6 million hectares. The UNDP estimates that 80,000 hectares of forest are being cleared annually for charcoal and timber, whereas it was only 50,000 in 2004 (UNDP, 2013); estimates range from $0.9 \%$ to $3.1 \%$ of forest being lost annually (Environmental Alert, 2009: 10). The Ministry declares that Uganda has had a "wood deficit" since 2000 (2015: 1) and concludes that the entire industry is "poorly regulated and...unsustainable" (xvii; Mwaura et al., 2014). This crisis narrative, however, along with the available local and national statistics, occlude differences among different modes of production, tied into different political relations and driven by different actors. It is attention to these differences that is key to grasping the ecological, but also political and economic, consequences of charcoal production in Uganda.

That charcoal production in northern Uganda has only recently escalated makes sense. The Acholi sub-region of northern Uganda was ravaged by civil war from 1986-2006, during which over a million people - the entire population of Acholi sub-region - had been forcibly displaced by the Ugandan government into internment camps, some for over a decade (Finnström, 2008; Dolan, 2009; Branch, 2011). Upon return home from 2008 onwards, people found their fields and homesteads overgrown by trees. People had also been divested of their savings, in particular herds of cattle that were looted in the early years of the war, allegedly by the state. Without savings, encountering a 
landscape marked by years of absence, people took advantage of the vast reserve of trees to begin small-scale artisanal charcoal production for cash. The main markets for the charcoal were probably the urban centres in northern Uganda itself, along with the multitude of smaller semi-urban agglomerations located on the sites of the former camps.

But a new market soon opened for this northern charcoal: Kampala. In the same years that Ugandans were returning to rural homes after displacement, independence in South Sudan created a new trade artery from Kampala north to Juba that passed through Acholi sub-region as South Sudan became the top destination for Uganda's exports (Ladu, 2018). The trucks carrying goods north to Juba had been returning south to Kampala empty, so filling them with charcoal became a way to make money off the return journey, as a sub-county chairperson along the highway explained to us. And so production developed to meet the Kampala demand, with people reporting that they would typically cut trees on their own land or nearby common hunting or forest land, burn and bag the charcoal on site using household labor, and then transport the bagged charcoal by foot, bicycle, or motorcycle to trading centers or main roads. There, the distinctive large white sacks of charcoal, up to a few dozen, would be propped up along the side of roads waiting for dealers or transporters who would buy and bring it to urban markets further south (Lawino, 2011). It could take weeks to produce one bag, often in a collective effort. It is hard to get solid historical prices of charcoal, but at the time of research, a sack was typically sold to dealers for about UGS 10-12,000, then sold at six to eight times that price in Kampala by retail vendors. 
This small-scale, household charcoal production continues at present. From our fieldwork, it appears that both men and women are involved, often using other members of the household or hiring neighbors for specific tasks, such as felling the largest trees. The reasons that people gave for burning and selling charcoal are familiar: poverty, a need for money for school fees, medical treatment, or household items. Some spoke of turning to charcoal production to compensate for falling productivity of land. Some women presented charcoal production as a way to obtain start-up capital for a small business or to join a village savings circle; young men spoke of saving for motorcycles to start an individual transport business. For the most destitute and landless, charcoal production was presented as their only opportunity to gain the income needed to buy food for survival. It was also presented as a strategy to compensate for poor harvests, whether caused by drought or other factors; as one community member explained in a location affected by elephant incursions: "We started burning charcoal due to poverty. This wasn't what we Acholi used to do. Most times the Acholi burned a little charcoal for cooking, but this was started for business because of the problem brought by the elephants. They eat everything of yours, so you start to struggle; you can cut some wood and, even if just one or two [bags] that you burn and sell, you can pay children in school. There is nothing else here."

The wood for charcoal was reported to come from farming land to which they had customary access, from communal forests, hunting, or grazing lands, or from rocky or hilly areas inaccessible for farming. Tools were basic: axes and machetes, with the burning done in rudimentary earth-mound kilns. It was reported that they would try to use fallen wood rather than living trees, and that, when trees were used, trunks or stumps would be left so that it could grow back. While appreciating the ready cash 
charcoal could bring, it was presented largely as an unfortunate necessity of the postwar period, but one that was thought to be sustainable given the basic tools and cutting practices and the limited forest that could be cut by household labor.

\section{The Violence of Industrial Charcoal Production}

Today, however, this livelihood, household charcoal production has been overwhelmed, at least according to many rural inhabitants and local leaders, by an industrialized, large-scale commercial model of production. ${ }^{4}$ The opening of densely forested land in the former conflict area after 2008 occurred as a perceived decline in wood supply was arising in areas further south, in particular Luweero and Nakasongola, which had been centers of charcoal production. A spike in prices also occurred during that time, which led to efforts to rapidly expand the supply (Shively et al., 2010; MEMD, 2013).

Industrial production appears to have grown on top of the existing networks of rural producers and small-scale transporters and dealers. As the collection of charcoal became regularized, truck drivers and small businesspeople began striking deals with community members in Acholiland to ensure a regular supply. But relying on household labor of mostly peasant farmers proved unable to meet the high demand. And so a major change began to occur as charcoal merchants started bringing in their own contracted work teams to cut the trees and burn and bag the charcoal on-site. Many communities we spoke to identified the change occurring around five or six years ago; in other places it has been more recent. In many cases, from discussions with the migrant work crews, it appears that production teams were simply moved 
north as the charcoal frontier shifted from areas of dwindling supply (Sserunjogi, 2014).

These merchants and work crews needed access to large areas of forested land, which was secured through various routes, as explained below. But the effect was clear: the rural community, instead of providing labor and controlling production themselves, became a bystander, watching as trees or entire forests were cut down by large work crews. The money accruing to rural inhabitants through sale of trees seems to be highly variable, especially as trees are sold through rough estimations; some reports have said anywhere from 100,000 to 1 million shillings are paid per acre (US\$25250); in other cases, landowners are paid 5000 shillings per bag of charcoal produced from trees on their land (Owich, 2016).

Contracted workers - many of them originally from Busoga, an area facing acute land pressures, food scarcity and drought - are brought in from the south of Uganda and placed in primitive work camps to clear-cut large swathes of forest. They typically use chainsaws, as crews of dozens or even hundreds of migrant workers can clear entire kilometers of land of trees. Large trucks are a ubiquitous feature of the landscape as they ply remote dirt roads and tracks, ferrying workers and supplies in and innumerable sacks of charcoal out. Trading centers are filled with huge piles of hundreds or thousands of white sacks of charcoal, and Karuma, the main crossing point of the Nile and truck stopover, sometimes has mountains of sacks being reloaded before their trip to Kampala. 
This new industrial production is decried as being far more intensive and destructive than household production. Work crews are accused of extracting even the roots of trees and leaving behind cratered landscapes of burning pits and the few bushes too small to burn. Community members denounced the ecological devastation they saw as caused by the mass extraction of trees. The most widespread and acute grievance was the perception that tree cutting was leading to decreased rainfall and higher temperatures, dramatically affecting crop yields. As a group of women in a village in Amuru District explained: "Yes, [tree cutting] is there. They cut almost everything, they started way from up there to all the way down. Now there's nothing, the rain has also gone silent and now, for us, we are dying of hunger because the ground has dried up. We are going to die of hunger, there is nothing to eat - you see this, they come and cut everything." In a nearby parish, a similar account was provided: tree-cutting “is ruining the forest. There isn't any forest anymore. You know that the forest also brings rain and prevents the wind. Now the forest isn't here to stop the wind and bring the rain." Another respondent explained that, "For me, I answer like this: because of charcoal burning, hunger has come in. Charcoal has thrown hunger our way." Such accounts point to the destructive character of industrial charcoal production, which is transforming localities in northern Uganda into enclaves where the maximum quantity of high-demand resources can be extracted at lowest cost within shortest period of time. This accords with the logic described by Raj Patel and Jason Moore (2017), in which the capitalist frontier expands to control and transform nature, thus maximizing flows of commodities from specific areas before shifting elsewhere once the boom of resource extraction has been exhausted. Again, however, this is not an inherent logic to charcoal production, as it has the possibility of being a renewable resource under different modes of production. Charcoal's current ecological destructiveness has 
political causes, as we outline below, and so the question is why charcoal production and trade has taken this specific form, a form that reprises the broader geography of energy injustice and development in Uganda, privileging the south at the expense of the north. ${ }^{5}$

Beyond changing rainfall, there were further reported damaging impacts of industrial charcoal production upon livelihoods. In particular, the commons that all depended upon for firewood, medicinal plants, grazing lands, and building materials were being destroyed. One local leader remarked that no one could find poles or grass for huts, and many communities reported a loss of access to firewood. People described how the loss of trees was also destroying the foundation for communal solidarity as the physical reference points for traditional authority within the community were being erased. A spiritual devastation followed, as the homes for spirits and trees with significant historical resonance were being cut and shipped off. And so it is little surprise that the industrial production was subject to such intense and uniform community outrage.

\section{The Force behind Industrial Extraction}

Industrial charcoal production and transport had a clear ethnic and political valence. The industrial charcoal trade was presented as being dominated by people from southern Uganda, who were an obvious presence among the charcoal dealers on the roads and trading centers of the north, as well as among the truck drivers and workers who burn the charcoal and load the trucks. But not only are the workers and transporters perceived to be from the south of Uganda; it also appears that the 
industry is dominated by a handful of Kampala-based elites. From research in Kampala markets and in the North, it appears that significant vertical and horizontal integration characterizes the industry. A handful of big dealers, it is reported, own fleets of trucks, buy sections of forests, and bring in their own workers to produce the charcoal. They then sell the charcoal to retail outlets in Kampala for 65,000 to 70,000 shillings, depending on the quality, which is then sold for 80,000 for a sack or sold in smaller quantities for a higher profit. This vertical and horizontal integration is ignored by the dominant academic and policy literature: the Ministry's Biomass Energy Strategy, for instance, declares that the solution is to "attract investors with substantial cash outlay" and not "leave charcoal production $100 \%$ in the hands of unorganized capital strapped producers" (75) - ignoring the fact that this is exactly what has happened and has led to such destructive consequences.

Another crucial aspect of industrial charcoal extraction, according to rural communities, local organizations, and local government officials, has been entirely unnoted by the academic and policy literature. This is the alleged involvement of the Ugandan state and military. In interviews, it was almost always explained that the charcoal traders and transporters were not operating on their own. Rather, they were said to have state coercion on their side. Considering Uganda's contemporary political economy, it is not a surprise to hear reports that the state and military are involved in the charcoal trade. The Ugandan state and military - a military-political-business elite - have long been deeply involved in business and extractive industries, often using force to acquire land or concessions, and have been condemned in the past for their involvement in the looting of natural resources in neighboring countries (Sjögren, 2013; Fisher and Anderson, 2015; Mwenda, 2007). Militarized, forceful 
displacements of communities by the state, whether for minerals, game reserves, parks, infrastructure, agri-business, or personal accumulation, are often enforced through military violence (Martiniello, 2015a; Carmody and Taylor, 2016; Lyons, Nel and Westoby, 2017); indeed, many of the large commercial farms owned by state elites are reported to be guarded by the Ugandan military (Ocungi 2018). Charcoal, especially when regulation can be avoided, provides an opportunity for significant profit by controlling the trade from start to finish through significant vertical integration, as one person with capital and political connections can pay for access to land, bring in work crews, and transport the product to Kampala, all underpinned by free military force. Another dimension of the assertion of state authority occurs through the manipulation of property regimes and land institutions, which allows the state to enhance its control over land and territory. According to Boone (2014) land conflicts and shifting land tenure regimes in Africa, which she divides into 'neocustomary and state land' (65-67), do not only result from the increasing intensity of commoditization, but also result from the making of particular property institutions which are intertwined with issues of political authority, citizenship, political identity and ethnicity.

Military and state involvement in charcoal extraction has led to a very direct connection between its violence and an aspect of the violence of the civil war: those driving the tree cutting are often identified as the very people who had been at the forefront of the government counterinsurgency in Acholiland. Ugandan military officers, it is said, got to know the Acholi countryside during the war and returned afterwards to exploit its resources. There had been a small amount of logging of hardwoods while the war was going on, it appears, but looting escalated dramatically 
in the post-war period, sometimes literally following the same routes as the counterinsurgency: many of the security roads that were cut by the Ugandan military during the war for their military vehicles to reach remote locales are now used to extract charcoal and timber. As one informant put it, "The people who bring their workers...to produce charcoal here are military commanders...the army commanders are Banyakole [President Museveni's ethnic group]". It was reported that transporters would be accompanied by military without uniforms and that traders and burning crews were sometimes armed. As one informant put it, "The government workers also give the rich people permission to cut the trees in that even if you complain, nothing will be done for you....Those people have security that we can't stop." After clearcutting, cattle also thought to belong to state or military elites and similarly guarded may be brought in to graze on the newly opened land.

Many communities reported that local government was reaping significant profits from collaborating with charcoal dealers and thus had no interest in ending the trade, however destructive. Those tasked with trying to regulate it expressed helplessness: the district leadership blamed corrupt sub-county officials, and vice-versa; but many also cited the involvement of high-ranking political or military elites. This was discussed sometimes openly, but often in slightly more hushed tones. Some officials spoke confidentially about arresting illegal charcoal dealers and impounding their charcoal and then suddenly getting a call from military headquarters demanding that the person be released. Trucks impounded today and gone tomorrow; drivers or merchants arrested today and released tomorrow. Others talked openly of local leaders being in the pay of charcoal dealers (Omona, 2016). And some human rights activists reported having received threatening phone calls when they were seen as 
interfering with charcoal dealers or traders. A rare public statement was made by the Local Council 5 Chairman of Amuru district, who, after imposing a ban on production, reported receiving threats: "I have names and recorded voices of the big persons in government and the army which I will expose if they continue" (Omony, 2016). The result has been that the powerful, those connected with the state and backed up by its security services, are seen as operating with impunity in cutting down trees for charcoal and timber, their power underpinned by the constant threat and occasional deployment of force.

More research would be needed in order to determine the full extent and nature of the state and military's involvement; however, this research would be risky if not impossible and the gains to be obtained are uncertain. For what we know already is that, whether the state and military officials are the large traders themselves, are investors or business partners for traders, or are providing favors to politicallyconnected businesspeople, the fact that military force seems to be involved both at the production and transport stages indicates that their integration into the industry is extensive. The end of the war thus did not mean the end of state violence in the north; instead, it appears to have taken on different forms. As one informant described it, the community was now experiencing "the war that has been waged against trees" as a continuation of a war against people that concluded a decade ago. That war had been largely experienced by Acholi civilians as the state, in collusion with international forces, destroying their conditions for life, livelihood, and community, in particular through its devastating policy of forced internment (Branch 2011). Today's charcoal industry, as part of a wider regime of state-led extractivism, is experienced in the same way. And so charcoal production cannot be understood without placing it within 
this legacy of the war: a militarized, unaccountable, extractive, state that seems willing to sacrifice the people of northern Uganda for its own gain and with impunity.

\section{Internal Politics of Charcoal Production}

The state force behind the charcoal industry helps to explain why industrial production has proceeded at such a rapid rate despite widespread community outrage and negative media attention. But access to land and trees has largely been acquired without major explicit violence against communities, which has been a feature of land and resource grabs by the state elsewhere in Uganda (Martiniello, 2015a). To understand why industrial charcoal production has been able to proceed with the consent of some members of the community - in a context, of course, of the overarching threat of state violence - often through negotiating access to trees instead of simply seizing access, it is important to understand how charcoal extraction is also enabled by, and exacerbating, the major fractures within the community along intercommunity, class, gender, and generational lines. These fractures are also largely a legacy of the war.

Most land in Acholi is held under customary communal tenure within a complex, changing system, with significant differences among different parts of the sub-region (Hopwood, 2015; Martiniello, 2015a). The war and displacement introduced new uncertainty into customary tenure: stories are often told about how elders who knew land boundaries and regulated land access have died or lost authority; trees, stones, or creeks that had demarcated different pieces of land have been lost. The years after the war have been a time of intense land wrangles between individuals, families, 
communities, clans, and with the rich and powerful (Atkinson and Owor, 2015).

These wrangles have been exacerbated by pressures for individualization, formalization, and titling of tenure, as well as by expansion of commercial farming (Martiniello, 2015b). Widespread perceptions prevail of a state campaign to grab land for politically-connected elites and international capital, and stories abound of local or national elites securing land at the expense of the poor and powerless. Such perceptions of land insecurity have been made more acute by the recent attempt of the Ugandan government to amend article 26 of the 1995 Constitution. Under current legislation, the state needs to provide fair and adequate compensation in case of takeover of private land earmarked for public projects. The proposed Land Bill would instead allow the state to forcefully confiscate land if it is deemed to be of national developmental importance while a legal adjudication proceeds. The system is one in which very cash-poor people, or people with little capacity for farming, can sometimes lay claim to large parcels of land, while elites can accumulate large portions through money or power. Existing regimes governing usufruct rights to trees also appear unprepared to deal with the extraction of trees on a commercial scale. And finally, it is a context in which the main source of savings for most Acholi before the war - cattle - are yet to be restored, and so people's capacity for dealing with poor harvests or sudden expenses is extremely thin.

In this context, people provide access to forested land or sell trees for different reasons and in different ways. That section of the cash-poor who are able to lay claim to customary land with trees - whether their own farming land or communal hunting or grazing land - may sell trees because of poverty and a lack of savings. Youth are often blamed as having been corrupted during the war and displacement by a "quick 
money" mentality and driven by individual greed instead of community wellbeing. Responding to this reputation, one young man explained: "what are you going to do to stop these people from coming and offering us money for our trees? Because if they offer us the money, we are going to have to take it!" But people also recognized that those selling trees often reaped little benefit; as one informant put it, "they sell among the outsiders and all the money remains theirs" - again, replicating the north-south divide entrenched during the war. Some selling trees for subsistence described being stuck in a vicious cycle: the poorest rely the most upon forests, whether through medicinal herbs and plants, hunting, firewood, providing shade, rain, and windblocks. As the commons are lost and rainfall decreases, sustainable smallholder farming becomes even more difficult. Natural habitats and, by consequence, smallholders' harvests are negatively affected by a combined and cumulative series of pressures, including insecure land access, irregular rainfall and floods, deteriorating soil fertility, wetlands encroachment, commercial cotton production, the presence of wild animals such as elephants, and distress caused by insects. Moreover, the shifting agricultural calendar has altered the pattern of inter- and mixed-cropping that had previously characterized agriculture in the sub-region and had allowed for efficiently combining sorghum, millet, simsim, pigeon peas, cassava and sweet potatoes. In such a context of expanding de-agrarianization of rural livelihoods and the absence of state policy supporting smallholders' agriculture or family farming, "charcoal money is our compensation," as one respondent put it. People rely on charcoal money even as it is perceived to worsen the conditions making them sell trees, as people are violently forced into the position of doing what they know will undermine their future survival in order to survive today. 
Another reason given for cutting down or selling trees for charcoal was insecurity over land, in particular fear that government was going to take away "idle" land. This is also a product of the war, as the policy of forced internment was seen by many Acholi as a strategy by the state to vacate the land and take it over, and the idea that the state seeks to exterminate the Acholi or turn them into laborers on their own land remains prevalent. In some cases, rumors that the government was going to declare a forest reserve led people to cut down or sell trees to destroy the forest and prevent its being grabbed: "People are cutting trees because they have been told that [government] do not want people here because this is forest land ...so people have decided that if it is like that we shall do away with the trees." As another informant explained, "Here we don't have enough information, there is a rumor that Amuru district wants to give away this area to a certain white investor. That is why people are selling trees with the hope that at least we would have gained [something] from the land."

These relatively poor tree-sellers might be distinguished from relatively well-off treesellers, who may be rural elites, commercial farmers, or absentee landowners. These actors can take advantage of often unclear, in-flux, and unenforced customary land arrangements, sometimes using state violence. The connection between local elites and state power was intensified during the war, which saw a contingent of Acholi collaborators reap economic and political profit in the midst of general destruction. Tree sales are a new subject of intense contention, as they are cut from land that several communities or households lay claim to, from communal grazing or hunting lands over which there is disagreement over use rights. Stories abound of individuals living in town who suddenly sold off all the trees on "his" land and pocketed a hefty 
sum. Cutting trees also removes disputed land out of the commons by insulating it from the multitude of claims that can arise from complex and contested customary tenure. In some cases, land owners were reported to be cutting down trees and then planting pine or eucalyptus monocultures - an activity reportedly enjoying extremely high rates of return on the order of $15-18 \%$, according to the Uganda Investment Authority - either for timber or to be eventually burned in improved kilns in anticipation of a "green" charcoal market - an ironic aspect of "green development" (Byakagaba and Muhiirwe, 2017; Lyons and Nel, 2017).

Tree-selling seems to have a strong gender dimension, given the tendency for men to have greater authority over land access and use. Again, gender conflicts have been a notable facet of the post-war context, during which men have sought to re-establish authority lost during the war through asserting their "traditional" control over land tenure (Branch, 2013; Hopwood, 2015). One woman explained that the only person making money from selling trees was "The landowner who sells the trees. You who have no husband, you don't get anything." And those without any claim to land can even be faced with expulsion: "People like us, who are squatting on people's land, we have nothing to show, even the land owners now wants to chase us away from their land."

As noted, there is a significant debate in the charcoal literature over the drivers of deforestation, in particular how to weigh charcoal's impact against agricultural expansion. There is little research done on this issue in Uganda (Khundi et al., 2011), although in western Uganda's Albertine Rift, Twongyirwe (forthcoming) identified agricultural expansion - commercial and small-scale sugarcane plantations - as the 
leading factor affecting the forested landscape of the region. Agricultural expansion seems a major driver in northern Uganda as well, where, in some instances, trees were clearly being cut as a result of the rapid expansion of commercial farming. However, there was also a common accusation that the claim to be cutting trees to open land was a ruse to cover for profitable tree-selling. The introduction of incentives for deforestation through commercial charcoal production appear to be changing decisions about whether to put more land under production, under tree plantations, or to rent it for commercial agriculture. This testifies to the complexity of the relations among different factors producing deforestation (Bergmann et al 2018; Iiyama et al, 2017).

From interviews and anecdotal evidence, therefore, while small-scale, household production was apparently supplementing incomes, industrial charcoal production seems to be producing greater inequality within the community, as those with the power to sell many trees profit, while those who had benefited from forests suffer. This is exacerbating many of the social and economic consequences of the war. Ecological devastation, increasing inequality, desperation for the future - these are the results of the violence of charcoal. They are linked closely with the legacy of the war: a militarized state with a history of violence against the civilian population; uncertainty and fear over security of land access combined with increasing insecurity over weather; easily exploitable divisions within society and the presence of landhungry politically connected elites and cash-poor rural elites - all this provided a fertile ground for the mass extraction of trees. Charcoal production is one aspect of the broader regime of state-driven, militarized extractivism that has taken shape in northern Uganda since the end of the war. Some people see themselves as being 
sacrificed for the financial interests of the state, whether through extracting value through oil, scarce minerals, sugar cane, sand and rocks, infrastructure, eco-tourism, conservations schemes, sugarcane, GMO seeds, soybeans, water, refugees, cloned eucalyptus, or, of course, indigenous trees. This resonates with the context described by Barney (2015), as charcoal is one of a series of natural resources that is overexploited in succession, "ushering the countryside into a reinforcing spiral of environmental degradation and underdevelopment" (205).

In this context, some solutions to deforestation proposed by rural communities reflect that violent political reality. Desperation at state impunity led a woman in a hard-hit area to announce at a local government meeting that they should "just kill" all the southerners burning charcoal. In one case, a community attacked a camp of workers and killed one and injured over 30 others (Otim, 2016). Enforcement missions by district leadership resort to arresting and beating charcoal dealers or transporters, since no other form of punishment or regulation may seem possible (Odokonyero, 2017; Omony 2016). And a woman who said she had been a rebel herself said that the solution was for the community to be given guns - "we know how to use them, we can solve this ourselves."

\section{Fantasies of Charcoal Futures}

The violence of charcoal extraction, the legacy of the war in shaping it, and the reality of large-scale industrial production and its destructiveness - all these tend to be ignored in the academic and policy literatures. Instead, small-scale livelihood production is taken to be the norm, and so the ecological and social devastation of 
industrial production is blamed on community members involved in livelihood production. Some invoking this storyline tend to sympathize with the producers, recognizing the poverty that has placed them in such desperate straits and calling for the provision of alternative livelihoods; others, especially urban local elites and government, condemn rural producers as greedy, short-sighted, and ignorant, in need of punishment and sensitization (Ojara, 2015). But both fail to distinguish between small-scale household production and large-scale industrial extraction and their very different politics, and both make poor rural people responsible for causing and solving what those rural people themselves know to be caused by much larger political and economic structures.

Unable to face the political reality of the charcoal industry, solutions proposed by NGOs and development agencies tend to focus on "improving the value chain." A recent UNDP report explains the solution is a "holistic one" to ensure poverty alleviation, a regular energy supply, local environmental sustainability and contribution to climate change mitigation. This includes the introduction of improved kilns and cooking stoves, along with "the creation and institutionalization of a charcoal unit at the district level that is charged with purchasing from producers, categorizing the type produced so producers can be paid a differentiated value based on whether or not the product is sustainable, and arranging transport from the districts to Government-created warehouses located outside urban areas. At the warehouses, the charcoal will be sold by retail associations." (UNDP, 2013: 9). These win-win narratives are, at present, a world of fantasy. Indeed, Uganda has long been characterized by a gulf separating the good governance, neoliberal development, climate change adaptation, and human rights that exist in the reports and plans of 
Uganda's international donors, from the reality of a militarized state reliant on Western donor money and coercive extraction presiding over precarious rural and urban populations.

This state shapes charcoal as an energy source, just as charcoal provides much of the power that fuels this state by making Uganda's rapid urbanization possible, without which rural crises could take on even more dramatic form. Cheap and accessible charcoal helps buy the acquiescence of the urban population, where political opposition is concentrated and where the threat of urban uprisings remains significant (Branch and Mampilly, 2015). There are reports that charcoal is the key fuel for industry, especially steel mills; if this is true, then the Ugandan government's alliance with the country's small industrial sector may also be dependent upon cheap charcoal. And ensuring a plentiful charcoal supply takes pressure away from the development of other sources of energy, whether gas or electricity, allowing those industries to be a source of rents for the state or politically connected elites.

But, as Mitchell argues, today's forms of energy entail certain political limits that are entangled with ecological limits. In the case of charcoal in northern Uganda, its particular mode of extraction and production, with its attendant ecological destruction, has been made possible because of political violence and the legacies of the war. And so, as long as the politics of the industry remain as they are, the rapid extension of the charcoal frontier, leaving deforested and degraded landscapes in its wake, is unlikely to end soon. Further exacerbating this tendency is that the destruction of the commons is a precondition for visions of extractivist development, from which the state and domestic and international capital derive significant profit. 
However, as the charcoal extraction frontier reaches the South Sudan border, it is not clear where else it can go within Uganda, and so new, violent, regional fuelscapes may soon be emerging. The rapid expansion of tree-planting for charcoal, more sustainable wood cutting practices, introduction of improved kilns and stoves, development of alternative biofuels: these might help make Uganda's own forest stocks last longer within the industry's current configuration. But without attention to the role that state power and the history of the war are playing in today's charcoal production and trade, these regulatory and technological fixes may well be inadequate. The destructiveness of charcoal will prove far more intractable than expected, and these de-politicized, technical, solutions may only hide and entrench deeper problems of political inequality and violence. The result may be that more forceful and organized resistance may arise among those losing their commons so that elites can profit.

\section{Works Cited}

Ainembabazi, J., Shively, G., \& Angelsen, A. (2013). Charcoal production and household welfare in Uganda: A quantile regression approach. Environment and Development Economics, 18(5), 537-558.

Arnold, J.E.M., Köhlin, G., Persson, R. (2006). Woodfuels, Livelihoods, and Policy Interventions: Changing Perspectives. World Development, 34(3), 596-611. 
Atkinson, R.R., and Owor, A. (2013). 'Land Grabbing': The Ugandan Government, Madhvani, and Others Versus The Community of Lakang, Amuru District. Journal of Peace and Strategic Studies, 1, 49-63.

Bailis, R., Drigo, R., Ghilardi, A., \& Masera, O. (2015). The carbon footprint of traditional woodfuels. Nature Climate Change, 5(3), 266-272.

Barnes, D.F., Krutilla, K., Hyde, W. (2004). The urban household energy transition: energy, poverty, and the environment in the developing world. Washington, DC: Resources for the Future.

Barney, K. (2016). Sparking development or consuming the countryside? Lao charcoal commodity networks in the Mekong Region. Asia Pacific Viewpoint, 57(2): 194-206.

Baumert, S., Luz, A.C., Fisher, J., Vollmer, F., Ryan, C.M., Patenaude, G., ZorrillaMiras, P., Artur, L., Nhantumbo, I., Macqueen, D. (2016). Charcoal supply chains from Mabalane to Maputo: Who benefits? Energy for Sustainable Development, 33, $129-138$.

Bergmann C., Roden, P., Nüsser, M. (2018). Contested fuelscapes: Producing charcoal in sub-Saharan drylands. Area. 00:1-9. https://doi.org/10.1111/area.12394

Bernstein, H. (2010). Class dynamics of agrarian change. Fernwood Publishers. Boone, K. (2014) Property and Political Order in Africa: Land Rights and the Structure of Politics. Cambridge University Press (2014).

Boyer, D. (2014). Energopower: An Introduction. Anthropological Quarterly, 87(2), 309-333. 
Branch, A. (2011) Displacing Human Rights: War and Intervention in Northern Uganda. New York: Oxford University Press.

Branch, A. (2013) Gulu in War... and Peace? The Town as Camp in Northern Uganda. Urban Studies, 50(15), 3152-3167.

Byakagaba, P., Muhiirwe, R. (2017) Industrial forest plantations in Uganda: Local adjacent community perspectives. Journal of Sustainable Forestry, 36(4), 375-387.

Cavanagh, C. and Benjaminsen, T. (2014) Virtual Nature, Violent Accumulation: The 'spectacular failure' of carbon offsetting at a Ugandan National Park. Geoforum, 56, $55-65$.

Cavanagh, C.J., Vedeld, P.O., and Trædal, L.T. (2015). Securitizing REDD+?

Problematizing the emerging illegal timber trade and forest carbon interface in East Africa. Geoforum 60, 72-82.

Chidumayo, E.N., Gumbo, D.J. (2013) The environmental impacts of charcoal production in tropical ecosystems of the world: A synthesis. Energy for Sustainable Development, 17(2), 86-94.

Doggart, N. \& Meshack, C. (2017). The Marginalization of Sustainable Charcoal Production in the Policies of a Modernizing African Nation. Frontiers in Environmental Science, 5(27).

Dolan, C. (2009). Social Torture: The Case of Northern Uganda, 1986-2006. New York: Berghahn Books. 
Environmental Alert. (2009). Diagnostic study on small and medium forests enterprises (SMFEs) in Uganda. Kampala.

Fairhead, J., and Leach, M. (1995). False forest history, complicit social analysis: Rethinking some West African environmental narratives. World Development, 23(6), 1023-1035.

Fairhead, J., and Leach, M., eds. (1998). Reframing Deforestation: Global Analyses and Local Realities: Studies in West Africa. Routledge.

Finnström, S. (2008). Living with Bad Surroundings: War, History and Everyday Moments in Northern Uganda. Durham, NC: Duke University Press.

Fisher, J., and Anderson, D.M. (2015). Authoritarianism and the securitization of development in Africa. International Affairs, 91, 131-151.

Gore, C. (2017). Electricity in Africa: The Politics of Transformation in Uganda. (James Currey).

Hardin, G. (1968). The tragedy of the commons. Science, 162(3859), 1243-1248.

Hiemstra-van der Horst, G., Hovorka, A.J. (2008). Reassessing the 'energy ladder': Household energy use in Maun, Botswana. Energy Policy 36, 3333-3344.

Hopwood, J. (2015). Women's land claims in the Acholi region of Northern Uganda: what can be learned from what is contested. International Journal on Minority and Group Rights, 22(3), 387-409.

Huber, M. (2015). Theorizing Energy Geographies. Geography Compass, 1-12. 
Iiyama, M., Neufeldt, H., Njenga, M., Derero, A., Ndegwa, G. M., Mukuralinda, A., Dobie, P., Jamnadass, R., \& Mowo, J. (2017). Conceptual analysis: The charcoalagriculture nexus to understand the socio-ecological contexts underlying varied sustainability outcomes in African land- scapes. Frontiers in Environmental Science, 5, 1-14.

International Energy Agency. (2014). Africa Energy Outlook. Paris.

Jerven, M. (2013). Poor numbers. Cornell: Cornell University Press.

Jones, C. F. (2016). Petromyopia: Oil and the Energy Humanities. Humanities, 5(36).

Ladu, I.M. (2018) “South Sudan: How Should Uganda do Business this Time?” Daily Monitor (Kampala), 24 July.

Laker, G. (2014) Uganda: Environmental Conflicts As Acholi Return Home. Fahamu. 20 March.

Lawino, S. (2011) Uganda: Acholi Forests in Danger As Charcoal Becomes Gem. Daily Monitor (Kampala). 21 September.

Leach, G., and Mearns, R. (1988). Beyond the woodfuel crisis: People, land and trees in Africa. London: Earthscan Publications.

Lenhart, L. (2013). Alleged Land Grabs and Governance: Exploring Mistrust and Trust in Northern Uganda - The Case of the Apaa Land Conflict. Journal of Peace and Strategic Studies, 1, 64-85. 
Lyons, K., Westoby, P. and Nel, A. (2017). Reforming global carbon markets or reimagining alternative climate solutions and sustainabilities? An analysis of selected NGO strategies in Uganda. Journal of Political Ecology, 24, 200-341.

Mann, D., Namuskisa, J., and Ndibwami, A. (2014). Energy and Urbanisation in Uganda: Context report and Literature Review. Uganda Martyrs University, Uganda.

Martiniello, G. (2015a). Social struggles in Uganda's Acholiland: understanding responses and resistance to Amuru sugar works. The Journal of Peasant Studies, 42(3-4), 653-669.

Martiniello, G. (2015b).Food Sovereignty as a Praxis? Rethinking the Food Question in Uganda. Third World Quarterly, 36(3), 508-525.

MEMD (Ministry of Energy and Mineral Development) (2007). The Renewable Energy Policy for Uganda. Government of Uganda.

MEMD (Ministry of Energy and Mineral Development) (2013). Biomass Energy Strategy (BEST) Uganda. Government of Uganda, with support of UNDP.

MEMD (Ministry of Energy and Mineral Development) (2016). National Charcoal Survey for Uganda 2015. Final Report. Government of Uganda.

Minten, B., Sander, K., Stifel, D. (2013). Forest management and economic rents: Evidence from the charcoal trade in Madagascar. Energy for Sustainable Development, 17(2), 106-115.

Mitchell, T. (2011). Carbon Democracy: Political Power in the Age of Oil. London: Verso. 
Miteva, D.A., Kramer, R.A., Brown, Z.S., Smith, M.D. (2017). Spatial Patterns of Market Participation and Resource Extraction: Fuelwood Collection in Northern Uganda. American Journal of Agricultural Economics, 99(4), 1008-1026.

Moore, J. and Patel, R. (2017). A history of the world in seven cheap things. Berkeley: University of California Press.

Mozersky, D., and D.M. Kammen. (2018). South Sudan's Renewable Energy Potential. USIP. Washington, DC.

Mukwaya, P.I. (2016) Urban Adaptation to Energy Insecurity in Uganda. Current Urban Studies, 4, 69-84.

Mwampamba, T., Ghilardi, A., Sander, K. \& Chaix, K.J. (2013). Dispelling common misconceptions to improve attitudes and policy outlook on charcoal in developing countries. Energy for Sustainable Development, 17, 75-85.

Mwaura, F., Okoboi, G., and Ahaibwe, G. (2014). Determinants of Households' Choice of Cooking Energy in Uganda. EPRC Research Series No. 114, Kampala. Mwenda, A. (2007). Personalizing Power in Uganda. Journal of Democracy, 18(3), 23-37.

NPA (National Planning Authority). (2013) Uganda Vision 2040. Government of Uganda.

Ocungi, Julius (2018). UPDF General cited in Nwoya land grabbing. Daily Monitor (Kampala), 17 August. 
Odokonyero, M. (2017). Uganda: A Run for Trees, Mukono Man Hurled in an Acholi Forest and What It Means. Daily Monitor (Kampala), 21 April.

Ohunakin, Olayinka S., et al. (2014). Solar energy applications and development in Nigeria: drivers and barriers. Renewable and Sustainable Energy Reviews 32: 294301.

Ojara, E. (2015). Nwoya Farmers Seek for Trees in Game Park due to Deforestation. Acholi Times, 14 December.

Omona, C.E. (2016). Strong Wind Blows off Roofs in Pabbo, Residents Say gods Angry over Tree Cutting for Charcoal. Acholi Times, 2 May.

Omony, D. (2016). Top Government officials, Army Bosses Intimidating me over charcoal - Amuru LC5 Boss. Acholi Times, 23 October.

Oroma, G. (2008) The forgotten 'victim' of the northern Uganda war. Daily Monitor (Kampala), 4 June.

Otim, D. (2016). One Dead, 32 injured, 200 Flee Amuru Revenge Attack. Acholi Times, 12 June.

Owich, J. (2016) Amuru Officials Slap Ban On Commercial Tree Cutting. Acholi Times, 17 June.

Peluso, N.L., and Watts, M.,eds. (2001). Violent Environments. Cornell University Press. 
Rembold, F., Oduori, S.M., Gadain, H., Toselli, P. (2013). Mapping charcoal driven forest degradation during the main period of Al Shabaab control in Southern Somalia. Energy for Sustainable Development, 17(5), 510-514.

Ribot, J. (1998). Theorizing Access: Forest Profits along Senegal's Charcoal Commodity Chain. Development and Change, 29, 307-341.

Sander, K., Gros, C., \& Peter, C. (2013). Enabling reforms: Analyzing the political economy of the charcoal sector in Tanzania. Energy for Sustainable Development, $17(2), 116-126$.

Schure, J., Ingram, V., Arts, B., Levang, P., and Mvula-Mampasi, E. (2015). Institutions and access to woodfuel commerce in the Democratic Republic of Congo. Forest Policy and Economics, 50, 53-61.

Shively, G., Jagger, P., Sserunkuuma, D., Arinaitwe, A., Chibwana, C. (2010). Profits and Margins along Uganda's Charcoal Value Chain. The International Forestry Review, 12(3), 270-83.

Sjögren, A. (2014). Scrambling for the promised land: land acquisitions and the politics of representation in post-war Acholi, northern Uganda. African Identities, $12(1), 62-75$.

Sjögren, A. (2013). Between Militarism and Technocratic Governance: State Formation in Contemporary Uganda. Kampala: Fountain Publishers.

Smith, H., Hudson, M., \& Schreckenberg, K. (2017). Livelihood diversification: The role of charcoal production in southern Malawi. Energy for Sustainable Development, $36,22-36$. 
Smith, H.E., Eigenbrod, F., Kafumbata, D., Hudson, M.D., \& Schreckenberg, K. (2015) Criminals by necessity: the risky life of charcoal transporters in Malawi. Forests, Trees and Livelihoods, 24(4), 259-274.

Sola, P., et al. (2017) The environmental, socioeconomic, and health impacts of woodfuel value chains in Sub-Saharan Africa: a systematic map. Environmental Evidence, 6(4).

Sovacool, B.K., and Dworkin, M.H. (2014). Global Energy Justice. Cambridge University Press.

Sserunjogi, E.M. (2014). Is Uganda Prepared for the Looming Charcoal Crisis? Sunday Monitor (Kampala), 14 September.

Twongyirwe, R. (Forthcoming). Revisiting the drivers of deforestation in the Tropics: Insights form local and expert knowledge in the Albertine Rift Landscape in Western Uganda. Journal of Rural Studies.

UNDP. (2013). Nationally Appropriate Mitigation Action Study on Sustainable Charcoal in Uganda. New York.

UNEP, INTERPOL, 2014. The Environmental Crime Crisis: Threats to Sustainable Development from Illegal Exploitation and Trade in Wildlife and Forest Resources. UNEP/GRID, Arendal, Norway.

Urry, J. (2014). The problem of energy. Theory, Culture and Society, 31(5), 3-20. 
van der Kroon, B., Brouwer, R., van Beukering, P.J.H. (2013). The energy ladder: Theoretical myth or empirical truth? Results from a meta-analysis. Renewable and Sustainable Energy Reviews, 20, 504-513.

Vanderheiden, S. (2011). The politics of energy: an introduction. Environmental Politics, 20(5), 607-616.

Wandera, D. (2016). Nadduli Slams North Leaders On Charcoal. Daily Monitor (Kampala), 6 July.

Watts, M. (2009). Oil, Development, and the Politics of the Bottom Billion. Macalaster International, 24, 79-130.

White, B., Borras, S.M. Jr., Hall, R., Scoones, I. \& Wolford, W. (2012). The new enclosures: critical perspectives on corporate land deals. Journal of Peasant Studies, 39(3-4), 619-647.

WWF (2015). Energy Report for Uganda: A 100\% Renewable Energy Future by 2050. WWF-World Wide Fund For Nature - Uganda Country Office. Kampala.

Zulu, L. and Richardson, R. (2013). Charcoal, livelihoods, and poverty reduction: Evidence from sub-Saharan Africa. Energy for Sustainable Development, 17, 127137.

\footnotetext{
${ }^{1}$ As Mwampamba et al (2013) point out, these data cannot necessarily be taken as entirely representative, due to a significant data scarcity largely resulting from the clandestine nature of production, poor regulation and informality. They also point out
} 
the sometimes huge discrepancies between IEA and FAO data. The unreliability derives also from an underlying politics of numbers, in which states, donors, and other development agencies act as gate-keepers in the production of knowledge about development, including its indicators, measures, and representations (Jerven 2013). ${ }^{2}$ There is a wider literature on the relation between political violence, peacebuilding, and energy, in particular around oil in Nigeria and South Sudan (Ohunakin et al 2014; Mozersky and Kammen, 2018). However, these are generally dealt with within the resources literature, without particular attention to their being sources of energy, as Mitchell (2011) seeks to do. The most attention to charcoal integrated into conflict is currently in Somalia, with some attention to Virunga in DRC (Cavanagh et al., 2015; UNEP Interpol, 2014).

${ }^{3}$ This article is written by two members of the research team, which included XXX. In total, twenty-five discussions were held. The discussions were held in the Acholi language and then transcribed and translated into English. A dozen individual interviews were conducted, all in English. Research ethics clearance was approved by the Makerere University College of Humanities and Social Sciences Research Ethics Committee, and permission was granted by the Ugandan National Council of Science and Technology. Funding was provided by XXX.

${ }^{4}$ There is a need for research to determine the actual breakdown between these different forms of production in northern Uganda, which we hope future projects can help determine. Right now, our argument is based upon qualitative data and perceptions of community members, local officials, civil society, and others.

${ }^{5}$ Research is expanding into Uganda's national energy politics, sparked by the recent dam-building and infrastructure projects, the rapid incursion of solar, and of course the development of oil resources (see Trotter, 2016; Gore, 2017). 